\title{
The Influence of College Students'Autonomous Learning on English Scores
}

\author{
Sa Yang \\ School of Educational Science and Technology \\ Huanggang Normal University \\ Huanggang, China \\ Email: 794228513@qq.com
}

\begin{abstract}
The purpose of this study is to help college students develop their independent learning ability and improve their English performance. In this study, we issued questionnaires, used SPSS software to conduct statistical analysis of the survey data and proposed some suggestions about college students' autonomous learning. The results show that college students' independent learning ability and English learning score are closely related. Our results also report that self-efficacy, goal setting, meta-cognition and the willpower control level have a higher correlation with English scores. It is surprising that autonomous learning English about 1-2 hours has the most impact on English final grade, while self-learning English about more than 2 hours has the greatest impact on CET-4 scores. The innovation of the article is that we use quantitative methods to explore the relationship between internal influence factors of college students' autonomous learning ability and English performance.
\end{abstract}

Keywords-college students; autonomous learning ability; English score; influence

\section{INTRODUCTION}

In the Internet age, with the development of China and frequent contacts with the international community, there is an increasing need for a large number of senior professionals who have the professional knowledge, skills and the ability of mastering English. So college students are precisely the best candidates. College students have spent a lot of time to learn professional knowledge, but English learning time is relatively inadequate. So developing their English self-learning ability and improving the efficiency of English learning are particularly important. This study is mainly based on the theory of Weiguo Pang about the internal influence factors of autonomous learning ability. That is to divide the internal influence factors of self-directed learning ability into selfefficacy, attribution, goal setting, cognitive strategy, metacognitive development level, level of willpower control and gender role [1]. Hope that college students can develop their independent learning ability and improve their English performance through learning from the recommendations of this paper.

Sponsor: 2015 Provincial Department of Education Humanities and Social Sciences Research Special Task Project in Hubei, China. The name of the project is Research on Postgraduate Study Style Construction (Project ID: 15Z150).

\author{
Huixia Wang* \\ School of Educational Science and Technology \\ Huanggang Normal University \\ Huanggang, China \\ Email: hellon_123@163.com
}

\section{The Relevant Theoretical Research}

\section{A. The Definition of Autonomous Learning}

Autonomous learning theory was proposed by scholars based on cognitive learning, humanistic learning and constructivist learning in the 1960s. By consulting the literature, the definition of autonomous learning is different, but its basic meaning is the same. Autonomous learning can be understood as the learning style, method, intensity and mode of learning result evaluation. It can also be understood as a student' s ability and habits to guide, control, and regulate learning behaviors. Zimmerman and others inherited the thought of personal, behavioral and environmental interactive determinism of Bandura. They thought that autonomous learning was decided not only by themselves, but also by an interaction of environmental events and behavioral events Influence; the self, behavior and environment were mutually causal and influence each other. [2] Dr. Tingting Wang, who works in East China Normal University in China, summed up the analysis of the various statements: autonomous learning was a proactive construction of the learning process, in which the learner could not only adjust their own cognition by setting goals, planning, selecting strategies, correcting strategies, monitoring results and other activities based on their metacognitive knowledge and task-related knowledge in related fields, but also regulate their own motivation to control the intention and be ensure that the goal of achieving in the face of difficulties [3].

\section{B. The Content of Self-Learning Ability}

Although researchers have not reached a consensus on the concept of autonomous learning ability and how to improve learners' autonomous learning ability, researchers all agree that the improvement of autonomous learning ability plays a decisive role in the simultaneous improvement of foreign language learning achievement. Zimmerman confirmed that autonomous learning ability would affect students' academic performance; students with higher self-learning ability were more likely to get high scores; students with weak self-learning ability tended to score unsatisfactory [2]. The Chinese scholar Duqin Wang, who was through the cultivation of college students learning strategies to develop students' ability to learn independently, found that the improvement of self-learning ability and progress of academic achievement are closely related [5]. 


\section{Factors Affecting Autonomous Learning Ability}

The factors that influence self-regulated learning are internal and external. Most Chinese researchers devote themselves to studying how to improve the autonomy of language learning through learning strategies training, especially meta-cognitive strategy training and willpower control level, and some researchers have studied how to improve their autonomous learning ability from other perspectives. Qian Guo in the form of speculation and Hua Weifen using empirical methods both discussed the relationship between motivation and goal setting and learner self-learning. The two researchers both believed that motivating learners to learn motivation and cultivating learner self-confidence had a positive effect on improving their autonomy[6]. Most scholars of the cognitive school represented by Bandura, such as Zimmerman, thought that the autonomous learning ability of students was mainly determined by their own internal instincts, needs, driving forces, traits, etc. There are two kinds of social cognition: the result of expectations and self-efficacy which effect and decide behavior [2].

\section{Review Summary}

The above studies interpret autonomous learning, autonomous learning ability and autonomous learning from different perspectives and have achieved some results. This study builds a framework of undergraduate students' autonomous learning ability from the perspective of the researcher Weiguo Pang. And the purpose is to analyze the internal factors that affect the ability of college students selflearning English. Specific framework is shown in Fig.1.

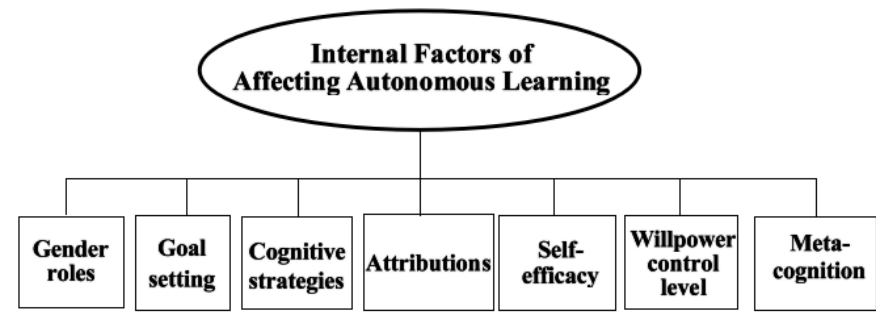

Fig. 1. framework diagram

\section{RESEARCH METHODS}

The main research methods used in this thesis are the questionnaire survey, literature review and statistical analysis.

\section{A. Questionnaire Method}

Before making the questionnaire, the author found that the factors that affect the ability of autonomous learning were divided into the following several aspects: self-efficacy, attribution, goal setting, acquisition of cognitive strategies, meta-cognitive development level, willpower control level and gender character. When designing the questionnaire, we designed different survey questions according to each aspect. There were many kinds of questions, including 20 questions. Before issuing a large number of questionnaires, the questionnaire was tested in a small area and this test data was analyzed by the SPSS. Then the survey questionnaire was modified through the test results and the relevant suggestions given by the testers. Finally, the questionnaire was distributed in a large area.

\section{B. Literature Research Method}

This paper obtained the literature mainly through accessing to online resources and collecting library materials. A wealth of online resources were include the SCI \& SSCI \& CPCI of library databases, Springer electronic journals, academic journals, master' s dissertation database, CNKI, etc. And the article also collected library paper resources.

\section{Statistical Analysis}

In this study, we used SPSS, which is the statistical analysis software. It is more clear, intuitive and easy to apply in statistical analysis. It has high reliability and can directly read the Excel and DBF data file.

\section{The Data Description and Variable Description}

\section{A. Sample Analysis}

This study mainly takes freshmen, sophomores, seniors and juniors undergraduates of Henan University of Science and Technology as study subjects, and the other college regions also issued questionnaires. The questionnaire was generated through questionnaire star electronic questionnaire, and then the study also did a anonymous distribution through the web, QQ and We Chat and other social software. A total of 350 questionnaires were distributed, 328 questionnaires were repossessed and 300 questionnaires were valid questionnaires. These include English majors and non-English majors. Based on the Recycling Scale, there were more women than men in terms of gender. There were far more non-English majors in English than in English majors. The reliability alpha value of collection data is $0.703(0.7<0.703<0.8)$, indicating that the scale had some problems in the design process, but the data still had the credibility.

\section{B. Variable Description.}

In this paper, the author studied the impact of autonomous learning on English achievement, mainly from seven influencing factors: self-efficacy, attribution, goal setting, cognitive strategy acquisition, meta-cognitive development level, and willpower control level and gender role. According to the analysis of survey statistical data, the specific description of the variable statistics is shown in Table I: 
TABLE I.

DESCRIBES THE VARIABLES

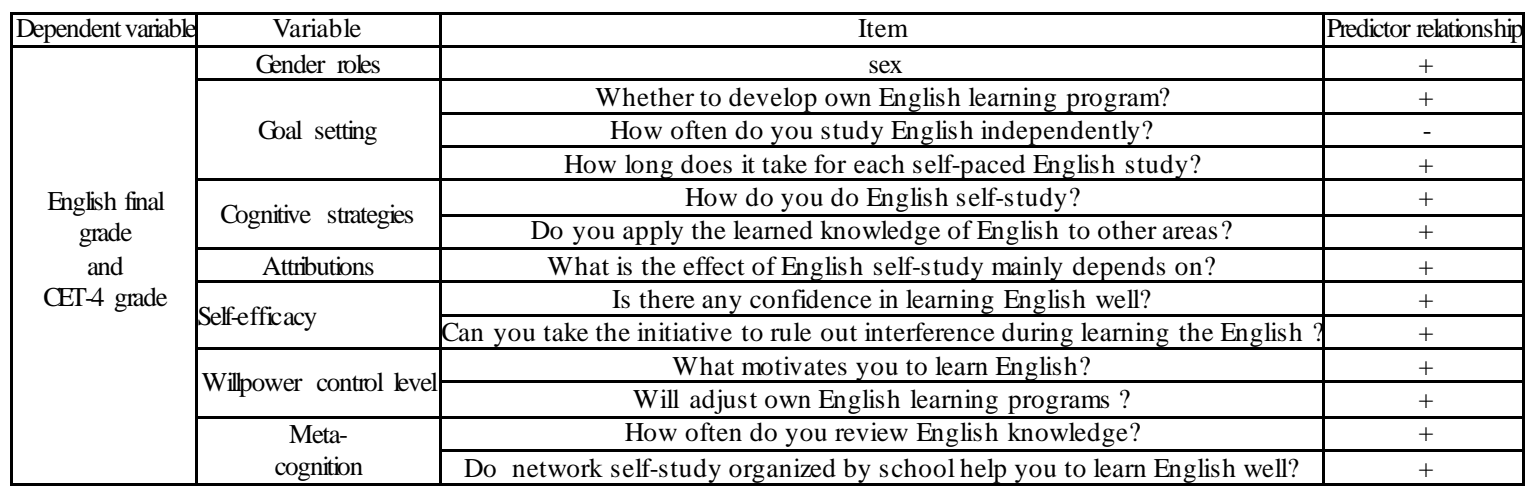

\section{Pearson Correlation Coefficient Test}

Through the Pearson correlation coefficient test on the seven influential factors in the questionnaire, the data analysis is shown in Table II. The study examined the impact of English learning by studying the factors that affect the ability of autonomous learning. The study found that this factors, selfefficacy, goal setting, meta-cognitive, attribution and willpower control levels, and English scores were relatively large, but cognitive strategies, gender roles and English scores was not obvious. The following statistics will be recovered detailed analysis.

TABLE II. CORRELATION ANALYSIS

\begin{tabular}{|c|c|c|}
\hline \multicolumn{3}{|c|}{ Pearson correlation coefficient } \\
\hline Gender & CET-4 grade & English final grade \\
\hline Confidence & $.134^{*}$ & $.298^{* *}$ \\
\hline Motivation Reasons & $.404^{* *}$ & $.491^{* *}$ \\
\hline Make leaming plan & -.007 & $.137^{*}$ \\
\hline Adjust leaming plan & $.234^{* *}$ & $.205^{* *}$ \\
\hline $\begin{array}{c}\text { Leam English } \\
\text { frequency autonomously }\end{array}$ & $.232^{* *}$ & $.250^{* *}$ \\
\hline $\begin{array}{c}\text { Leam English } \\
\text { time autonomously }\end{array}$ & $-.283^{* *}$ & $-.242^{* *}$ \\
\hline Eliminate interference & $.278^{* *}$ & $.228^{* *}$ \\
\hline $\begin{array}{c}\text { The way to leam } \\
\text { independently }\end{array}$ & $.340^{* *}$ & $.339^{* *}$ \\
\hline $\begin{array}{c}\text { The frequency of } \\
\text { English review }\end{array}$ & .008 & -.071 \\
\hline effectiveness & $.237^{* *}$ & $.248^{* *}$ \\
\hline $\begin{array}{c}\text { The help of } \\
\text { school network }\end{array}$ & $.174^{* *}$ & $.219^{* *}$ \\
\hline Knowledge application & $.210^{* *}$ & $.216^{* *}$ \\
\hline
\end{tabular}

* Significantly correlated at 0.05 level (bilateral)**significantly correlated at 0.01 level (bilateral)

1) Effects of Self-Efficacy Variables on English Grades

From Table II, we can see that "Confidence" is related to the final English score and the English CET-4 grade. The relevant coefficients are 0.491**, 0.404**and "Eliminate interference" is also related to the English final score and the English CET-4 grade. The relevant coefficients are 0.339** and $0.340^{* *}$, which are also relatively high. Therefore, there is a positive correlation between "English achievement" and "Confidence", and the correlation coefficient is the highest. Then this study conducted a single factor multiple analysis within the group, as shown below: 
TABLE III. “IS THERE ANY CONFIDENCE IN LEARNING ENGLISH WELL?” MULTIPLE COMPARISON(LSD)

\begin{tabular}{|c|c|c|c|c|c|c|}
\hline \multicolumn{3}{|c|}{$\begin{array}{l}\text { Variable: } \\
\text { (I)Is there any confidence in learning English well? } \\
\text { (J)Is there any confidence in learning English well? }\end{array}$} & \multirow[t]{2}{*}{ Mean difference (I-J) } & \multirow[t]{2}{*}{ Significance } & \multicolumn{2}{|c|}{$95 \%$ confidence interval } \\
\hline \multirow{9}{*}{ Dependent variable } & \multirow{5}{*}{ CET-4 grade } & $(\mathrm{J})$ & & & Lower limit & Upper limit \\
\hline & & $\begin{array}{|cc|}\text { very few } & \text { absolutely not } \\
& \text { commonly } \\
\text { a lot of }\end{array}$ & $\begin{array}{c}-.221 \\
-.520^{*} \\
-.1 .067^{*}\end{array}$ & $\begin{array}{l}.195 \\
.000 \\
.000\end{array}$ & $\begin{array}{c}-.56 \\
-.81 \\
-1.38\end{array}$ & $\begin{array}{l}-.11 \\
-.23 \\
-.75\end{array}$ \\
\hline & & \begin{tabular}{|l} 
Very few \\
$\begin{array}{c}\text { absolutely not } \\
\text { commonly } \\
\text { a lot of }\end{array}$
\end{tabular} & $\begin{array}{l}.221 \\
-.299 * \\
-.846 *\end{array}$ & $\begin{array}{l}.195 \\
.009 \\
.000\end{array}$ & $\begin{array}{l}-.11 \\
-.52 \\
-1.10\end{array}$ & $\begin{array}{l}.56 \\
-.08 \\
-.59\end{array}$ \\
\hline & & 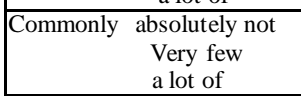 & $\begin{array}{l}.520^{*} \\
.299 * \\
-.547^{*}\end{array}$ & $\begin{array}{l}.000 \\
.000 \\
.009 \\
.000\end{array}$ & $\begin{array}{l}.23 \\
.08 \\
-.73\end{array}$ & $\begin{array}{l}.80 \\
.52 \\
-.36\end{array}$ \\
\hline & & 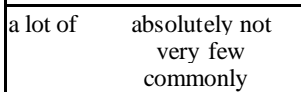 & $\begin{array}{l}1.067^{*} \\
.846^{*} \\
.547^{*}\end{array}$ & $\begin{array}{l}.000 \\
.000 \\
.000\end{array}$ & $\begin{array}{l}.75 \\
.59 \\
.36\end{array}$ & $\begin{array}{l}1.38 \\
1.10 \\
.73\end{array}$ \\
\hline & \multirow{4}{*}{ English final grade } & $\begin{array}{|cc|}\text { absolutely not } & \text { very few } \\
& \text { commonly } \\
& \text { a lot of }\end{array}$ & $\begin{array}{l}-.420^{*} \\
-.787 * \\
-1.455^{*}\end{array}$ & $\begin{array}{l}.017 \\
.000 \\
.000\end{array}$ & $\begin{array}{l}-.76 \\
-1.08 \\
-1.78 \\
\end{array}$ & $\begin{array}{l}-.08 \\
-.49 \\
-1.13\end{array}$ \\
\hline & & \begin{tabular}{|cc} 
very few & $\begin{array}{c}\text { absolutely not } \\
\text { commonly } \\
\text { a lot of }\end{array}$
\end{tabular} & $\begin{array}{c}.420^{*} \\
-.368^{*} \\
-1.035^{*}\end{array}$ & $\begin{array}{l}.017 \\
.002 \\
.000\end{array}$ & $\begin{array}{c}.08 \\
-.60 \\
-1.30\end{array}$ & $\begin{array}{l}.76 \\
-.14 \\
-.86\end{array}$ \\
\hline & & $\begin{array}{c}\begin{array}{c}\text { Commonly } \\
\text { absolutely not } \\
\text { very few } \\
\text { a lot of }\end{array} \\
\end{array}$ & $\begin{array}{l}.787^{*} \\
.368^{*} \\
-.668^{*}\end{array}$ & $\begin{array}{l}.000 \\
.002 \\
.000 \\
\end{array}$ & $\begin{array}{l}.49 \\
.14 \\
-.86 \\
\end{array}$ & $\begin{array}{c}1.08 \\
.60 \\
-.47 \\
\end{array}$ \\
\hline & & \begin{tabular}{|c} 
a lot of \\
$\begin{array}{c}\text { absolutely not } \\
\text { very few } \\
\text { commonly }\end{array}$
\end{tabular} & $\begin{array}{l}1.455^{*} \\
1.035^{*} \\
.668^{*}\end{array}$ & $\begin{array}{l}.000 \\
.000 \\
.000\end{array}$ & $\begin{array}{l}1.13 \\
.78 \\
.47\end{array}$ & $\begin{array}{c}1.78 \\
1.30 \\
.86\end{array}$ \\
\hline
\end{tabular}

As can be seen from the table above: self-confidence has a great impact on students' English CET-4 scores and English final scores. With the degree of self-confidence increasing, English learning will be relatively improved academic performance; learning power corresponding to people with self-confidence will be different. The higher the selfconfidence, the higher the learning efficiency. The degree of self-confidence is also related to the learning fun in the process of autonomous learning. The low self-confidence leads to the conflict of learning in the process of learning, thus affecting the learning achievement. On the contrary, those with high selfesteem will be willing to learn to go on their own initiative and they can be always studying.
Through multiple comparisons, we can also see that the factor, which is always possible to rule out the surrounding interference factors, has the highest relevance to the English final grade, as followed Table IV. It indicates that students' self-control ability and adaptability are both relatively strong, who are initiative to exclude the interference in the autonomous learning. Although everyone has strong and weak ability to rule out interference in the surroundings, this ability can be cultivated through the outside world. In addition, through active training, learners can not only improve their antiinterference ability, but also develop a higher self-control ability and adaptability.

TABLE IV. “CAN YOU TAKE THE INITIATIVE TO EXCLUDE THE SURROUNDING INTERFERENCE DURING THE ENGLISH LEARNING PROCESS?” MULTIPLE COMPARISON (LSD)

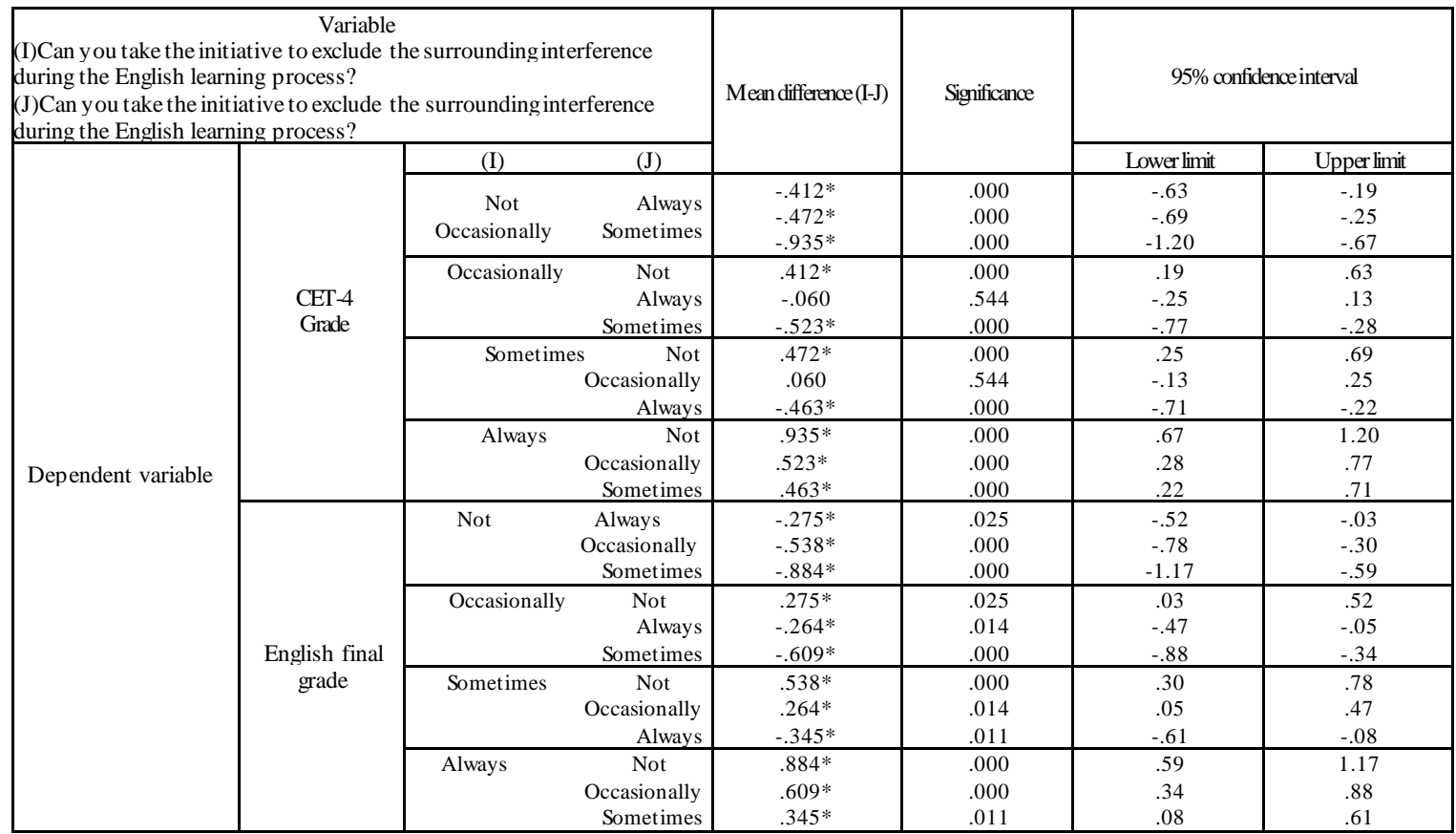


"Self-confidence" and "Eliminate interference" can all be considered as self-efficacy in the learning process. There is a positive correlation between self-efficacy and English achievement, which is consistent with our conjecture. The increase of self-efficacy helps to improve the English learning achievement, and has a very important influence on learning mood and learning motivation. Therefore, we suggest that learners should always maintain a high degree of selfconfidence in learning English independently and take the initiative to improve their ability to exclude interference around

2) The Impact of Goal Setting Variables on English Achievement

According to the correlation analysis in Table II, the correlation coefficients of "Make learning plan" and "Learn
English time autonomously” are respectively $0.234 * *, 0.205 * *$, $0.278 * *, 0.228 * *$, which are positively correlated with English scores. However, "Learn English frequency autonomously" has a negative correlation with CET- 4 and the final grades of English and the correlation coefficient is $-0.283 * *,-0.242 * *$. Although this coefficient is negative, it shows that conducting English self-study everyday can improve English scores more than weekly self-study. Therefore, "Learn English frequency autonomously", "Learn English time autonomously", "Make learning plan" and CET-4 grade, English final grade are significantly related. In fact, the target setting in autonomous learning has an impact on English score. And in these aspects, "How long does it take for each self-paced English study?" has a greater impact on English scores. Next we did a single-factor analysis of multiple factors about it, as shown in Table V.

TABLE V. “HOW LONG DOES IT TAKE FOR EACH SELF-PACED ENGLISH STUDY?” MULTIPLE COMPARISON (LSD)

\begin{tabular}{|c|c|c|c|c|c|c|c|}
\hline \multicolumn{4}{|c|}{$\begin{array}{l}\text { Variable: } \\
\text { (I)How long does it take for each self-paced English study? } \\
\text { (J)How long does it take for each self-paced English study? }\end{array}$} & \multirow[t]{2}{*}{$\begin{array}{l}\text { Mean difference } \\
(\mathrm{I}-\mathrm{J})\end{array}$} & \multirow[t]{2}{*}{ Significance } & \multicolumn{2}{|c|}{$\begin{array}{l}\text { 95\% confidence } \\
\text { interval }\end{array}$} \\
\hline \multirow{9}{*}{$\begin{array}{l}\text { Dependent } \\
\text { variable }\end{array}$} & \multirow{5}{*}{ CET-4 grade } & (I) & $(\mathrm{J})$ & & & $\begin{array}{l}\text { Lower } \\
\text { limit }\end{array}$ & $\begin{array}{l}\text { Upper } \\
\text { limit }\end{array}$ \\
\hline & & 30minutes & $\begin{array}{r}30-60 \text { minutes } \\
1-2 \text { hours } \\
>2 \text { hours } \\
\end{array}$ & $\begin{array}{l}.320^{*} \\
-.538^{*} \\
-.696^{*} \\
\end{array}$ & $\begin{array}{l}.001 \\
.000 \\
.000\end{array}$ & $\begin{array}{l}-.51 \\
-.77 \\
-1.04 \\
\end{array}$ & $\begin{array}{l}-.13 \\
-.31 \\
-.35 \\
\end{array}$ \\
\hline & & 30-60minutes & $\begin{array}{r}30 \text { minutes } \\
1-2 \text { hours } \\
>2 \text { hours } \\
\end{array}$ & $\begin{array}{l}.320^{*} \\
-.219 \\
-.377^{*} \\
\end{array}$ & $\begin{array}{l}.001 \\
.073 \\
.038\end{array}$ & $\begin{array}{l}.13 \\
-.46 \\
-.73 \\
\end{array}$ & $\begin{array}{l}.51 \\
.02 \\
-.02\end{array}$ \\
\hline & & 1-2hours & $\begin{array}{r}30 \text { minutes } \\
30-60 \text { minutes } \\
>2 \text { hours }\end{array}$ & $\begin{array}{l}.538 * \\
.219 \\
-.158 \\
\end{array}$ & $\begin{array}{l}.000 \\
.073 \\
.410\end{array}$ & $\begin{array}{l}.31 \\
-.02 \\
-.53\end{array}$ & $\begin{array}{l}.77 \\
.46 \\
.22 \\
\end{array}$ \\
\hline & & $>2$ hours & $\begin{array}{r}30 \text { minutes } \\
30-60 \text { minutes } \\
1 \text {-2hours }\end{array}$ & $\begin{array}{l}.696^{*} \\
.377^{*} \\
.158\end{array}$ & $\begin{array}{l}.000 \\
.038 \\
.410\end{array}$ & $\begin{array}{l}.35 \\
.02 \\
-.22 \\
\end{array}$ & $\begin{array}{l}1.04 \\
.73 \\
.53 \\
\end{array}$ \\
\hline & \multirow{4}{*}{$\underset{\text { grade }}{\text { English final }}$} & 30minutes & $\begin{array}{r}30-60 \text { minutes } \\
1-2 \text { hours } \\
>2 \text { hours } \\
\end{array}$ & $\begin{array}{l}. .180 \\
-.552^{*} \\
-.473^{*} \\
\end{array}$ & $\begin{array}{l}.094 \\
.000 \\
.016 \\
\end{array}$ & $\begin{array}{l}-.39 \\
-.80 \\
-.86 \\
\end{array}$ & $\begin{array}{l}.03 \\
-.30 \\
-.09 \\
\end{array}$ \\
\hline & & 30-60minutes & $\begin{array}{r}30 \text { minutes } \\
1-2 \text { hours } \\
>2 \text { hours } \\
\end{array}$ & $\begin{array}{l}.180 \\
-.372 * \\
-.293 \\
\end{array}$ & $\begin{array}{l}.094 \\
.006 \\
.144 \\
\end{array}$ & $\begin{array}{l}-.03 \\
-.64 \\
-.69 \\
\end{array}$ & $\begin{array}{l}.39 \\
-.11 \\
.10 \\
\end{array}$ \\
\hline & & 1-2hours & $\begin{array}{r}30 \text { minutes } \\
30-60 \text { minutes } \\
>2 \text { hours } \\
\end{array}$ & $\begin{array}{l}.552^{*} \\
.372^{*} \\
.078 \\
\end{array}$ & $\begin{array}{l}.000 \\
.006 \\
.711 \\
\end{array}$ & $\begin{array}{l}.30 \\
.11 \\
-.34 \\
\end{array}$ & $\begin{array}{l}.80 \\
.64 \\
.50 \\
\end{array}$ \\
\hline & & $>2$ hours & $\begin{array}{r}30 \text { minutes } \\
\text { 30-60minutes } \\
1 \text {-2hours } \\
\end{array}$ & $\begin{array}{l}.473^{*} \\
.293 \\
-.078 \\
\end{array}$ & $\begin{array}{l}.016 \\
.144 \\
.711 \\
\end{array}$ & $\begin{array}{l}.09 \\
-.10 \\
-.50 \\
\end{array}$ & $\begin{array}{l}.86 \\
.69 \\
.34 \\
\end{array}$ \\
\hline
\end{tabular}

Through the correlation analysis, we concluded that the time of each independent study of English was significantly related to CET-4 grade and English final grade. And from the multiple analysis the table above, it is surprising that autonomous learning English about 1-2 hours has the most impact on English final grade, while self-learning English about more than 2 hours has the greatest impact on CET-4 scores. CET-4 exam is a process of English accumulation, such as vocabulary, sentence etc. For the most important point, if you use the longer time to learn independently, you will be more mastery of English vocabulary and your CET-4 scores will be improved. Through the investigation and inquiry, we also found that college English final exam is relatively simple. As long as learners have some preparation knowledge, they could also be very good at the English examination without reviewing English. And the contents of English final exam are generally the contents of textbooks. The exam scope is not as wide as CET-4. The final exams are different ones and students are distracted on learning time. So autonomous learning English for more than two hours doesn't have the obvious effect compared with learning English for 1-2 hours.

3) The Impact of Meta-Cognitive and Willpower Control Variables on English Scores

As can be seen from the correlation analysis in Table II, the correlation coefficient of "Motivation Reasons" and English final grade is $0.137^{*}$. The correlation coefficient is moderately correlated. The correlation coefficients of "Adjust learning plan" and CET-4 scores, English final grades are $0.232^{* *}$ and $0.250 * *$ the correlation coefficient is highly correlated. "The frequency of English review", "The help of school network about self-study" and CET-4 scores, English final grades have the correlation coefficient of two stars. The correlation coefficient is high. Because "Motivation Reasons and Adjust learning plan” are the willpower control level variables, "The frequency of English review" and "The help of school network 
about self-study" are meta-cognitive factors, the willpower control level variables affect the ability of autonomous learning English achievement and the impact of meta-cognitive strategies on English achievement is very significant. This is entirely in line with our prior expectation. English learning is a long-term accumulation process, and it is very necessary to review English frequently. Therefore, it is suggested that learners focus on understanding memory and reviewing new knowledge in English learning.

4) The Effect of Attribution, Gender Role and Cognitive Strategy on English Scores

From the correlation analysis of Table II, it can be seen that the correlation between the effects of autonomous learning and English grade(English CET-4 grade, final grades)is $0.219^{* *}$ and $0.174 * *$. Therefore, the effectiveness of autonomous learning is related to English achievement. Attribution and English achievement is still positively correlated. Therefore, it is recommended that learners need to pay attention to the correct attribution, and adjust the learning methods in time to obtain better academic performance. The correlation coefficient between English CET-4 scores and the "sex" is 0.134 * and the corresponding coefficient of significance is 0.021 , which is less than 0.05 . Therefore, the factor of gender role is related to the English CET-4 grades, but not significant. While the correlation coefficient of the final grade with the gender is $0.298 * *$. Therefore, the gender role has more influence on the final grade than the CET- 4 grade. In addition, "The way to learn independently" and "Knowledge application" are also related to the English grades. On the whole, attribution variables, gender role variables and cognitive strategy variables have great relevance to English achievement.

\section{CONCLUSION AND RECOMMENDATION}

\section{A. Conclusion}

This article explored how self-learning ability affects English scores from seven factors such as self-efficacy, attribution, goal setting, cognitive strategies, meta-cognitive development, willpower control and gender roles. The results of this study are as follows: The performance, goal setting, attribution, meta-cognitive, willpower control level are obviously related to English scores, while cognitive strategies and gender roles is less related to English scores. Most notably, the study found that autonomous learning English 1-2hours had the most effect on the English final grade, while more than two hours of self-study had the biggest impact on the CET-4 scores, which was totally different from the expected result. The results show that learners should learn to choose autonomous learning time according to different situations. In addition, when studying English, students who take the initiative to improve their learning ability and review the new knowledge can greatly improve their English learning performance.

\section{B. Recommendations}

According to the findings of the study, this article gives some suggestions as below, which are intended to help college students to improve their self-learning ability and improve their English scores.

Firstly, not only should learners pay more attention to the self-efficacy of English learning, teachers should use teaching strategies to encourage learners during the English learning process so that students can enhance their confidence, strengthen the conviction of successful learning, and enhance self-efficacy sense.

Secondly, develop learners’ autonomous learning ability. Learners should understand the factors that affect the ability of autonomous learning, consider their own situation, and improve these factors. It is best to use the theoretical knowledge in English learning. For example, learners should be confident before studying. Then understand learning own goals, make plans, and finally persist in implementing own plans.

Thirdly, when learning English autonomously, learners should clearly define their own learning objectives, be good at choosing the appropriate method for their own study, and learn to flexibly adjust their study plans and methods. The most important thing is to adhere to their plan to resist the temptation to eliminate interference. Students do not give up self-learning English, and they need to review the English learned repeatedly.

Fourth, the majority of English educators in the teaching process had better actively guide students to the right attribution training. Specific methods are as follows: scenario cultivation method, model method, self-control method and strengthening method and so on.

\section{REFERENCES}

[1] Li Chen, “Distance Education,” Beijing: Beijing Higher Education Press, 2011, pp. 6-10.(In Chinese)

[2] Weiguo Pang, “Autonomous Learning: Learning and Teaching Principles and Strategies, ” Shanghai :East China Normal University Press, 2003, pp.4-5.(In Chinese)

[3] Tingting Wang, "Self-regulated Learning Process Motivation," Shanghai: East China Normal University Doctoral Dissertation, 2008.(In Chinese)

[4] Duren Wang, "Cultivating College Students' Autonomous Learning Ability,” Shanghai: Foreign Language World, vol. 5, 2002.(In Chinese)

[5] Qian Guo, "Using Formative Evaluation to Promote Learner Autonomy in College English Teaching," Xian: Journal of Xi'an International Studies University, 2004, pp. 66-68.(In Chinese)

[6] Zimmerman, B. J, "Becoming a Self-Regulated Learner: An Overview,” Ohio: Theory into Practice, vol. 41, 2002, pp. 64-70. 